\title{
Effective implementation of unprecedented measures for the protection from COVID-19 syndrome
}

\section{COVID-19 Sendromuna Karşı Alınan Olağanüstü Önlemlerin Etkin Uygulaması}

\author{
(10 Adem ÖZKARA1, (10 Katrina LAMBERT², iD Duygu AYHAN BAŞER33, iD Bircan ERBAS2
}

${ }_{1}$ University of Health Sciences Turkey, Department of Family Medicine, Ankara, Turkey

${ }^{2}$ La Trobe University, Public Health Department, School of Psychology and Public Health, Australia

${ }_{3}^{3}$ Hacettepe University Faculty of Medicine, Department of Family Medicine, Ankara, Turkey

\begin{abstract}
Despite 82 million populations, Turkey is one of the countries with the lowest mortality rates in the world as a result of successful crisis management and public compliance. Turkey's public health response to the COVID-19 pandemic has been rapid and continually evolving as described here. In this short communication we offer insight into the preparedness and response by Turkey of this continued global health threat posed by COVID-19. Turkey implemented multiple containment strategies prior to the first reported case within its borders- to reduce the burden and deadly risk of the virus. In the absence of a specific vaccine, governments, health care professionals and communities in general are continually working together to reduce exposure, infection, clinical severity and community transmission of COVID-19.
\end{abstract}

Keywords: Republic of Turkey, COVID-19, measures, public health

\section{ÖZ}

Türkiye, 82 milyon nüfusa rağmen, başarılı kriz yönetimi ve kamu uyumuna bağlı olarak dünyada COVİD-19'a bağlı en düşük ölüm oranına sahip ülkelerden biridir. Türkiye'nin COVİD-19 salgınına karşı toplum sağlığı olarak cevabı bu yazıda da açıklandığı gibi hızlı ve sürekli olarak gelişmektedir. Bu kısa derlemede, COVIDD19'un sürdürdüğü bu küresel sağlık tehdidine karşı Türkiye’nin hazırlık ve müdahale uygulamalarını sunuyoruz. Türkiye, virüsün yükünü ve ölümcül riskini azaltmak için sınırlarında bildirilen ilk olgudan önce birden çok sınırlama stratejisi uygulamıştır. Belirli bir aşının bulunamaması durumunda, COVID-19'un maruziyetini, enfeksiyon ve klinik şiddetini ve toplum bulaşını azaltmak için genel olarak hükumet, sağlık uzmanları ve toplum birlikte çalışmak durumundadır.

Anahtar Sözcükler: Türkiye Cumhuriyeti, COVİD-19, önlemler, toplum sağlı̆̆1
The global nightmare of a new strain of the coronavirus -COVID-19- is unprecedented and has not been seen since the 1918 influenza pandemic, placing extraordinary strains on health institutions, governments and communities. Currently, there are 14.562.550 confirmed cases worldwide, with 607.781 deaths reported (as of Jul 21). World Health Organization (WHO) declared COVID-19 a pandemic on March 11, 2020 as many countries grappled with the danger of the disease as it rapidly spread and reported deaths quickly rose (1). An urgent public health dilemma was emerging, and governments needed to take extraordinary steps to control and reduce community transmission to gain time and reduce the rapidly unfolding burden of COVID-19 while weighing up the foreseeable economic challenges likely to occur.

Address for Correspondence: Duygu AYHAN BAŞER, Hacettepe University Faculty of Medicine, Department of Family Medicine, Ankara, Turkey

E-mail: duyguayhan@outlook.com ORCID ID: orcid.org/0000-0002-5153-2184

Cite this article as: Özkara A, Lambert K, Ayhan Başer D, Erbas B. Effective implementation of unprecedented measures for the protection from COVID-19 syndrome. Bezmialem Science 2020;8(Supplement 2):63-66. 
The Republic of Turkey which is a bridge between Europe and Asia geographically was one of the first countries which implemented urgent and robust measures to slow the spread. The first case observed in Turkey was on March 10, 2020 approximately three months after the spreading of COVID-19 from the Wuhan city of China. The public health message and policies implemented from the Ministry of Health began well in advance of the first confirmed case. An operation centre was established on January 6, 2020, a Science Committee was established on January 10, 2020 and government initiated public health interventions were followed immediately. On January 14, the "COVID-19 Disease Guideline" was prepared by the Ministry of Health and the public was informed about all processes (2). Also COVID-19 Disease Guideline has been updated in line with the developments. Leadership was demonstrated with the communication of important information via social media and news coverage of the then epidemic. COVID-19 was at the forefront of every news item with effective statements made by experts and others famous names and celebrities pleading with the public not be complacent with the emerging crisis the country was facing, and the role of each citizen to ensure precautionary measures were implemented in the pre- first case period. Another step pre-first case was screening movement of incoming and outgoing of all persons within Turkey airports. Since January 20, all travellers from China's Wuhan city, Myanmar, Singapore, Thailand, America, Russia were screened and all passengers in all flights to risky areas were scanned with thermal cameras prior to departure. Citizens of the Republic of Turkey working/living in Wuhan, China were brought into Turkey and quarantined with no virus detected in any of these passengers at the end of quarantine period. After March 11, all flights were banned to China, South Korea, Iran, Iraq and Italy, and then flights to Germany, France, Spain, Norway, Denmark, Belgium, Austria, Sweden and the Netherlands were mutually stopped. Finally, this number increased to 359. All of this occurred well in advance to the spread. Field Hospitals were established on February 27 at eight border crossings with Iran, Iraq and Georgia. All travellers were required to comply with the 14-day quarantine rule to protect their fellow citizens. All state student dormitories were emptied for the quarantine process and healthcare personnel were provided for those in quarantine. Before the first case, all key health institutions in Turkey implemented urgent policies to adapt to surge in demand and the possibility of cases. In primary institutions all elective case reception ceased and as the number of cases emerged this practice was applied to all secondary and tertiary health intuitions which also developed emergency response and interventions. For example, to reduce the possibility of public contact with risky persons, elderly people with chronic illnesses and those with chronic diseases were provided alternative forms of care without the need to visit health institutions. As the first cases emerged, the government working closely with experts implemented drastic public health measures to ensure transmission reduction processes. These included early selfisolation, the closure of schools and the beginning of distance education learning, visitor restriction in prisons and hospitals, postponing overseas travel of public employees and continuing sporting events without spectators. Social distancing interventions were implemented immediately and mass gathering and activities of places where people congregated ceased. A donation campaign was launched to fight the disease. The Republic of Turkey, a predominately Muslim country made the key decision to forbid prayer collectively in mosques and places of worship and banned to Pilgrimage and Umrah visits to Saudi Arabia in 2020. Although, this was seen as a drastic measure by other countries early in the outbreak, the government and health experts were determined to reduce exposure and infection early. Government public health infrastructure increased immediately. As demand of personal protective measures during the pandemic peaked (3) the Vocational and Technical Anatolian High Schools with appropriate infrastructure began the production of disinfectant and surgical masks. Under the coordination of the Ministry of Health and the Ministry of Transport and Infrastructure, free mask distribution was initiated to all citizens aged 20-65. Even now, the Ministry of Health continues to distribute personal protective equipment to healthcare workers. Respiratory devices were produced and donated to hospitals by large companies. Applicable algorithms have been created in all health systems, including primary care, for COVID-19 and forwarded to all healthcare professionals for implementation (4). As cases began to emerge, all possible case definitions have been based on the WHO clinical and epidemiology profile of COVID-19. Respiratory tract samples have been studied in reference laboratories serving all 16 provinces. In addition, a new diagnostic screening kit was developed to give reliable and rapid results in the diagnosis of the disease (2). All provinces were provided with these kits and plans were implemented for immediate information transfer to the reference laboratories when new possible positive cases emerged. Curfews have been imposed on citizens over 65 years old, citizens with chronic illnesses without age restrictions and persons under 20 years of age. As of April 1, curfews began to be implemented on all citizens on weekends as part of the fight against the pandemic. As numbers began to decline, restrictions started to be removed significantly, as of Jun 1,on the condition of not neglecting the mask wearing, social distancing, cleaning rules; it has been decided to remove the travel restriction between cities, and to open social places within certain rules. Within the scope of coronavirus measures, the use of masks has been made compulsory in some provinces and substantial penalties are enforced, if not complied.

The Republic of Turkey was instrumental in implementing measures to assess risk and all departments within the ministry of health were actively engaged in Turkey's response. Critical information and expert opinion were communicated to the public in a transparent and timely manner to reduce the initial and subsequent peaks. There is no treatment for COVID-19 as vaccinations are currently been developed. As precautionary measures, strict measures need to be adopted to reduce the intensity and spread of the disease. The Ministry of Health, decision makers at all levels of government have undertaken strategies and worked collectively with health experts to provide transparent evidence of this rapidly evolving pandemic through social media, television channels and healthcare professionals 
at every opportunity (3). Systems, policy and procedures are constantly revised. With almost all countries affected, implementing strict broad scale social distancing and isolation measures may contribute to minimizing transmission and substantial burden on the hospital systems at which the rapid spread of the virus occurs.

At present over 4,359,627 tests for the novel coronavirus are being carried out daily in the Republic of Turkey, with 221.500 confirmed cases and 5,526 deaths as of Jul 21 (1). Although the second wave of the outbreak is imminent, effective interventions put in place by the Republic of Turkey may have slowed the speed of transmission and clinical severity of the infection, thereby slowing down this peak of the infection curve (5). To date, Turkey has a $2.5 \%$ mortality rate and is one of the countries with low rates due to the COVID-19 pandemic, which caused the death of six hundred and seventy thousand people worldwide (Table 1) (7).

The cautionary tale of countries with a higher burden of COVID-19 at an earlier date than ours (6) will enable the Republic of Turkey to continue to develop mitigation and containment strategies to be better prepared for the additional expected surge in cases COVID-19 threatens our world as we know it. To reduce this burden and deadly risk of the novel coronavirus, governments, health care professionals and communities in general need to work together to reduce exposure, infection, clinical severity and community transmission of COVID-19 for much longer than first anticipated.

Table 1. Cases/fatality rate and mortality by country of the COVID-19 pandemic (7)

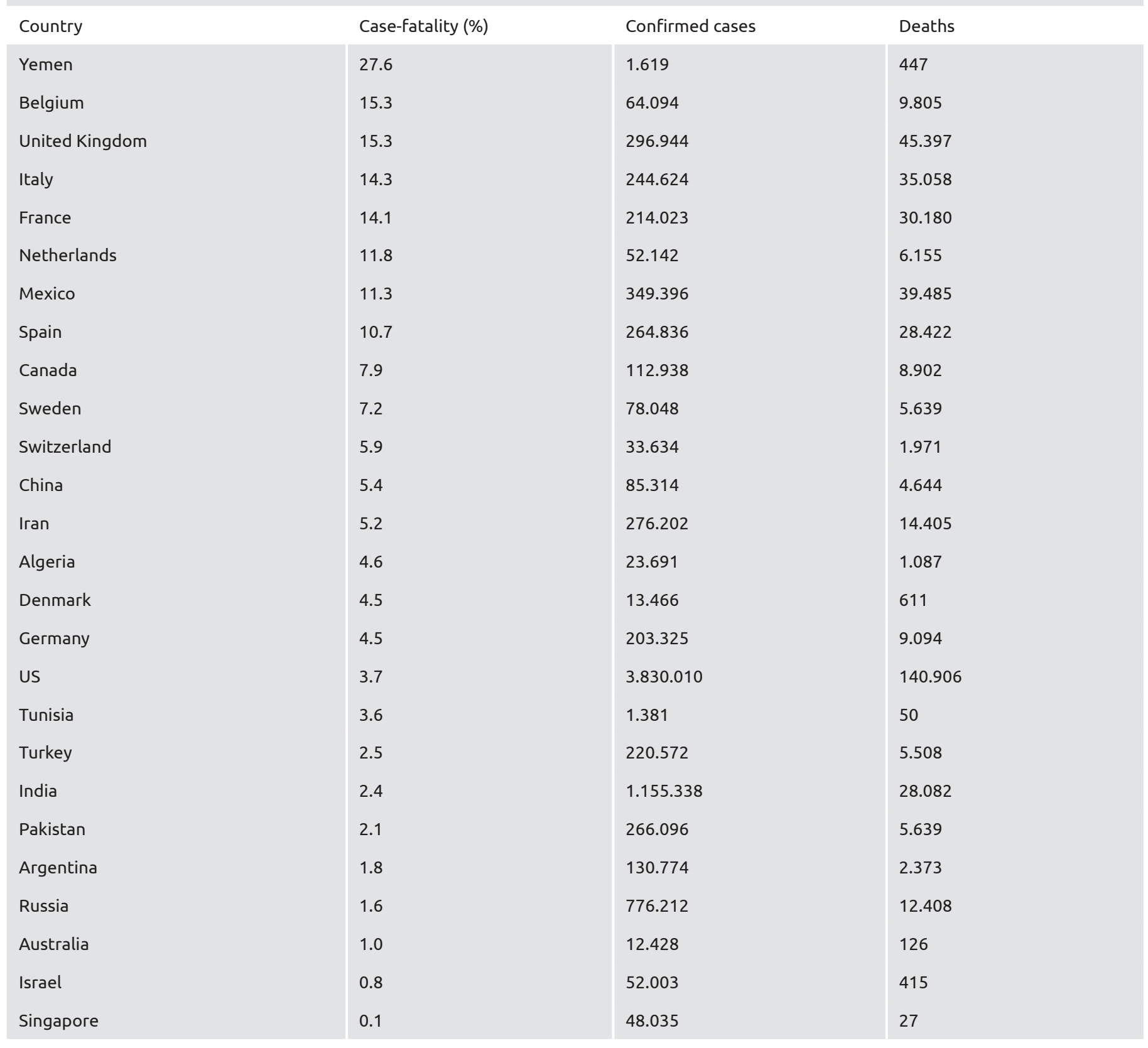


Peer-review: Externally and internally peer reviewed.

\section{References}

1. WHO 2020, Coronavirus disease (COVID-19) Pandemic Last Accessed Date :23.06.2020. Available from: https://www.who.int/ emergencies/diseases/novel-coronavirus-2019

2. T. C. Ministry of Health General Directorate of Public Health 2020. COVID-19 (SARS-CoV2 Infection) Guideline. Last Accessed Date: 23.06.2020. Available from: https://hsgm.saglik.gov.tr/depo/ covid19/Ingilizce/Rehber/COVID-19_Rehberi_Genel_bilgiler_ epidemiyoloji_ve_tani_8.06.2020_eng.pdf

3. Xu K, Cai H, Shen Y, Ni Q, Chen Y, Hu S, et al. Management of corona virus disease-19 (COVID-19): the Zhejiang experience. Zhejiang Da Xue Xue Bao Yi Xue Ban 2020;49:147-57.
4. Minister of Health of the Republic of Turkey, 2019 Yeni koronavirus enfeksiyonu vaka bilgi, sorgulama ve izlem formları Last Accessed Date: 23.06.2020

5. Anderson RM, Heesterbeek H, Klinkenberg D, Hollingsworth TD. How will country based mitigation measures influence the course of the COVID-19 epidemic? Lancet 2020;395:931-4. doi:https://doi. org/10.1016/S0140-6736(20)30567-5

6. Legido-Quigley H, Mateos-García JT, Campos VR, Gea-Sánchez M, Muntaner C, McKee M. The resilience of the Spanish health system against the COVID-19 pandemic. Lancet Public Health 2020;5:e251-2. pii: S2468-2667(20)30060-8. doi: 10.1016/S24682667(20)30060-8.

7. Mortalıty Analyses. Last Accessed Date: 26.06.2020. Available from: https://coronavirus.jhu.edu/data/mortality 